\title{
International Labor Migration and Remittances in Nepal
}

\section{Renuka Kumari Karki (M. Phil.)*}

\begin{abstract}
International migration and remittance are major areas of population and development. This study identifies the trend and destination of foreign labor migration in Nepal and highlights the flow of remittance status and its contribution to the gross domestic product in Nepal. This study is based on the secondary data collected from the various national and international organizations. Migration from Nepal has expanded tremendousl y since the mid-1990s, accompanied by a continuous broadening of the variety of destinations. Nepal has observed a rapid increase of absent population over census periods. International migration for work has changed significantly as is evident in the growing outflow of temporary migration of youths, both men and women, to work in newly emerging economies like Malaysia, Qatar, Saudi Arabia, and United Arab Emirates. Emigration has come to be recognized as an important factor both for changing ways of life of people and for the positive contribution to the nation's economy. In terms of remittance inflows as percent of GDP, Nepal is the third largest remittance receiver in the world. Taking all these factors into consideration, the only problem with it is that; until now, the government only seems to have adopted policies to encourage youth to find employment opportunities and provide remittance in turn but not for them to invest in productive sector to create more jobs and to retain working age population within the country.
\end{abstract}

Key words: International migration, remittance, GDP, globalization \& inflow.

\section{Introduction}

In today's increasingly interconnected world, international migration has become a reality that touches nearly all corners of the globe. Modern transportation has made it easier, cheaper and faster for people to move in search of jobs, opportunity, education and quality of life. At the same time conflict, poverty, inequality and a lack of sustainable livelihoods compel people to leave their homes to seek a better future for themselves and

\footnotetext{
*Ms. Karki is a Lecturer at the Department of Population Studies, Patan Multiple Campus, TU, Latitpur, Nepal. Email: bogatirenu7@gmail.com
} 
their families abroad. The numbers of international migrants worldwide have continued to grow rapidly in recent years, reaching 258 million in 2017, up from 220 million in 2010 and 173 million in 2000 . Over 60 per cent of all international migrants live in Asia 80 million or Europe 78 million. Northern America hosted the third largest number of international migrants 58 million, followed by Africa 25 million, Latin America and the Caribbean 10 million and Oceania 8 million (United Nations, 2017).

International migration in Nepal started with the recruitment of physically strong young people by then powerful countries. Slowly it became a livelihood strategy for a large part of the rural population. Nepal has 200 years long history of international labor migration. In 19th century, for instance, the first men migrated to Lahore (in today's Pakistan) to join the army of Sikh ruler, Ranjit Sing and those who went to Lahore earned the nick name "Lahure" which is still used today for Nepalese employed in foreign armies. Since then, international labor migration of Nepalese has never ceased. The formal labor migration however started in 1930s with organized industry but national structures came into existence in 1947 when labor movement started in Biratnagar.

The regional labor office was established in 1960s and the department of labor was established in 1971 followed in 1981 by Ministry of Labor (Gurung, 2004). Especially in recent decades it has greatly increased and diversified (Bhattarai, 2005). According to Nepal's population census 1.92 million persons i.e. 7.3 percent of the populations were abroad (CBS, 2014). Nepal is one of the important sources for migrant workers for the countries suffering from the labor shortage and migrant worker's remittance have become increasingly important source of income for the country. Migration trend shows that Middle East countries like Malaysia, Qatar, UAE and Saudi Arabia have been attractive destinations for Nepalese workers (MoLE, 2016).

Labor migration and remittance is becoming the important mainstay of Nepalese economy (Kollmair et al., 2006). As migrants have become used to sending money back to those they have left behind, their remittances have become an essential means of livelihood security for hundreds of thousands of poor families worldwide and a major source of foreign exchange for many low income countries. The amount of such transfers reached almost US\$ 300 billion in 2008 (World Bank, 2009).Remittances are not only defining household consumption and investment patterns, but are also transforming the structure and dynamics of the country's overall economy. In Nepal, remittances that migrants send home play a vital role in national development. It contributed 10.9 percentage share of the gross domestic product (GDP) in 2003/04 and 29.9 per cent (WB, 2019). The remittance flow, therefore, is a major contributor to development financing in Nepal. The 
outflow of migrants in the past decade has been momentous in transforming the country's economic, social and cultural fabric.

Movement of population across the international borders of Nepal has two components. The first is emigration, or the Nepal born population reported as absentees abroad, and second, immigration or the foreign-born population reported within Nepal. This study is limited only to the emigration. As the number of labor migrants every year increases, there is increasing share of international migrant workers remittance on GDP of Nepal. Nepali migrant workers continue to fill the labor gaps especially in Gulf Cooperation Council (GCC) countries and Malaysia. Nepal is the third-highest recipient of remittances as a share of GDP, among all countries and ranks first among the SAARC countries (WB, 2019).

\section{Objectives}

The main objective of this study is to identify the trend and destination of foreign labor migration in Nepal. The specific objectives of this study are to highlight the inflow of remittances and its contributions to the GDP of Nepal.

\section{Methodology}

The study is based on the secondary data collected from Department of Foreign Employment (DoFE), Ministry of Finance (MoF), World Bank and Central Bureau of Statistics (CBS). The secondary data has been employed in order to identify the trend in foreign employment as well as remittance and its contribution to GDP, which is presented for the past eight years, 2009/10-2016/17. The data for this study refers to the Fiscal Year. Simultaneously, the recent data for the year 2019 of remittance inflow has also been included.

\section{Data and Discussion}

\section{Trends of Labor Migration}

The government of Nepal formally allows Nepali nationals to go and work in 110 countries. However, majority of migrants are concentrated in the Gulf Cooperation Council countries (Bahrain, Kuwait, Oman, Qatar, Saudi Arabia, and the United Arab Emirates) and Malaysia. The lack of employment opportunities in Nepal is considered to be the major push factor for the increased volume of labor migration. 
The Department of Foreign Employment (DoFE) under the Ministry of Labor regularly updates the number of people going abroad by taking individual and institutional permission. A total of 3,289,668 labor permits were issued by the Department of Labor and Employment from 2009/10 through 2016/17.

Figure 1: Trends of labor migrants going abroad by taking official permission, 2009/10$2016 / 17$

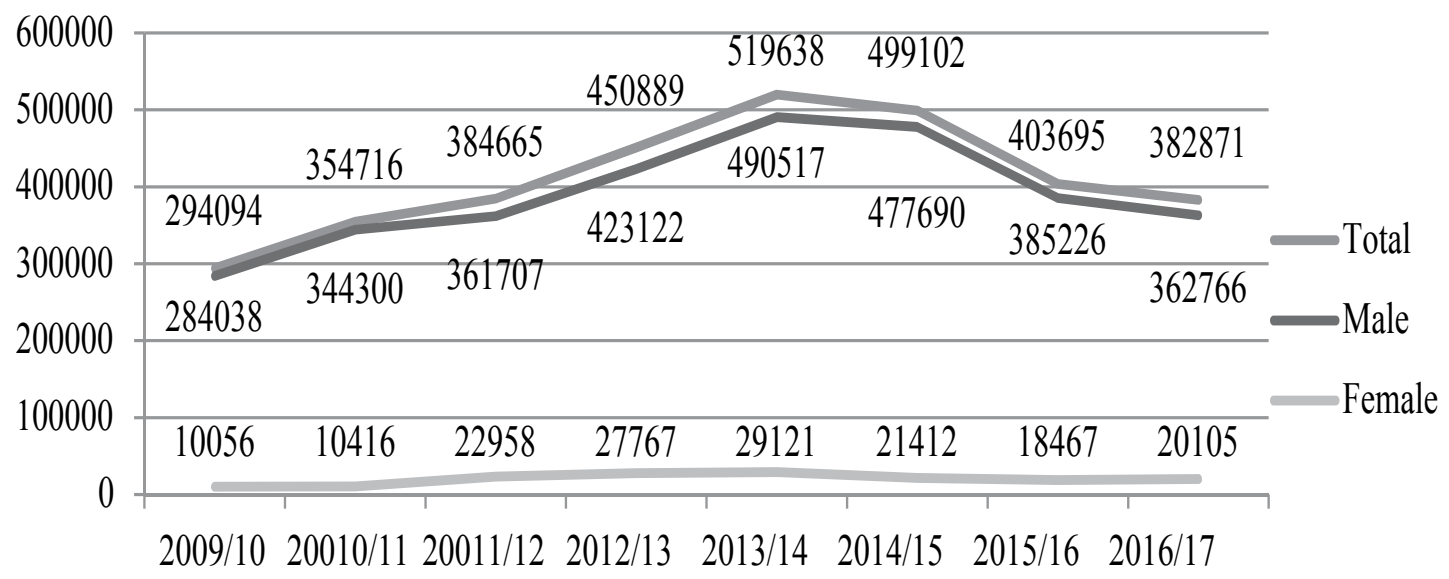

Source: DoFE, Labor Migration for Employment, 2018

Figure 1 shows that there has been steady increase in issued permits between 2009/10 to $2013 / 14$, but the numbers have declined from $2014 / 15$ to $2016 / 17$. The total number of workers migrating abroad has been increasing continuously. There are two responsible factors for such a growing trend of Nepalese workers going abroad for employment. These factors are pull factors and push factors. High demand of labor in industrialized and developed nations like East Asian nations, Middle East nations and Gulf nations are main pull factors. Dearth of employment opportunity in the nation, distorted peace and security, low wage level, lack of agricultural development in rural areas, scarcity of basic services needed for survival, liberal policies of government and demonstration effect are main push factors. International migration and paid-employment are male-dominated phenomena in Nepal. 
Figure 2: Percentage distribution of labor migration in Nepal by sex, 2009/10-2016/2017

\begin{tabular}{|c|r|r|}
\hline Year & Male (\%) & Female (\%) \\
\hline $2009 / 10$ & 96.6 & 3.4 \\
\hline $2010 / 11$ & 97.1 & 2.9 \\
\hline $2011 / 12$ & 94 & 6 \\
\hline $2012 / 13$ & 93.85 & 6.15 \\
\hline $2013 / 14$ & 94.4 & 5.6 \\
\hline $2014 / 15$ & 95.71 & 4.29 \\
\hline $2015 / 16$ & 95.42 & 4.58 \\
\hline $2016 / 17$ & 94.74 & 5.26 \\
\hline
\end{tabular}

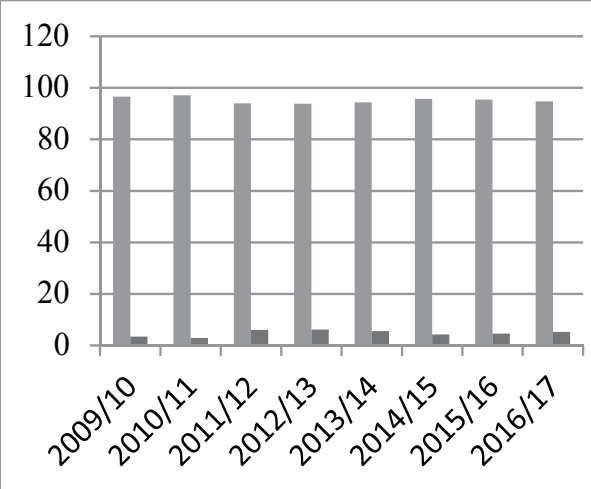

Male $(\%)$

- Female $(\%)$

Source: Department of Foreign Employment, 2018

The labor migration trend by sex is presented in figure 2. Although the increase in women migrant workers is significant in itself, it has had less impact on the overall trend in labor permits issued than the situation of men migrant workers: The yearly increase or decrease in overall labor permits issued is associated with the rise and fall in the number of male labor migrants. There was 5.26 percent increase in permits issued to female migrant workers in 2016/2017 compared to 3.4 percent in 2009/2010. The sharp decline among workers in female migrant workers travel as domestic workers in destination countries.

The 1961 census collected data on both internal and international migration on the basis of citizenship and place of birth. The total number of labor emigrants has increased significantly to 328,470 in $1961,3.4$ percent of the total population. Emigration data for the 1971 census is not available.

Table-1: Distribution of absent population in Nepal, 1961-2011

\begin{tabular}{|c|c|c|c|}
\hline Census Years & Total population & Absent population & \% of total population \\
\hline 1961 & $9,741,466$ & 328,470 & 3.4 \\
\hline 1981 & $15,425,816$ & 402,977 & 2.6 \\
\hline 1991 & $19,149,387$ & 658,290 & 3.4 \\
\hline 2001 & $23,499,115$ & 762,181 & 3.2 \\
\hline 2011 & $26,494,504$ & $1,921,494$ & 7.3 \\
\hline
\end{tabular}

Source: $C B S, 2003 \& 2014$ 
The 1981 census recorded an absent population of 402,977, 2.6 percent of the total population, which increased to 762,181 in $2001,3.2$ percent of the total population. In 2011 , the total number of absent population was reported to be 1,921,494, 7.3 percent of the total population. It shows that the absent population in Nepal is growing rapidly. Census 2011 reveals that one in every four households in Nepal is $(25.4 \%)$ is absent or is living outside of the country.

\section{Destination of Nepalese Migrants}

The Department of Foreign Employment data indicate that Nepalese labor migrants obtained a labor permit for employment in 153 destination countries. Malaysia, Qatar, Saudi Arabia, United Arab Emirates, Kuwait, had the larger numbers of permits granted of the total.

Figure 2: Major destination countries for Nepalese migrants worker, 2018/19

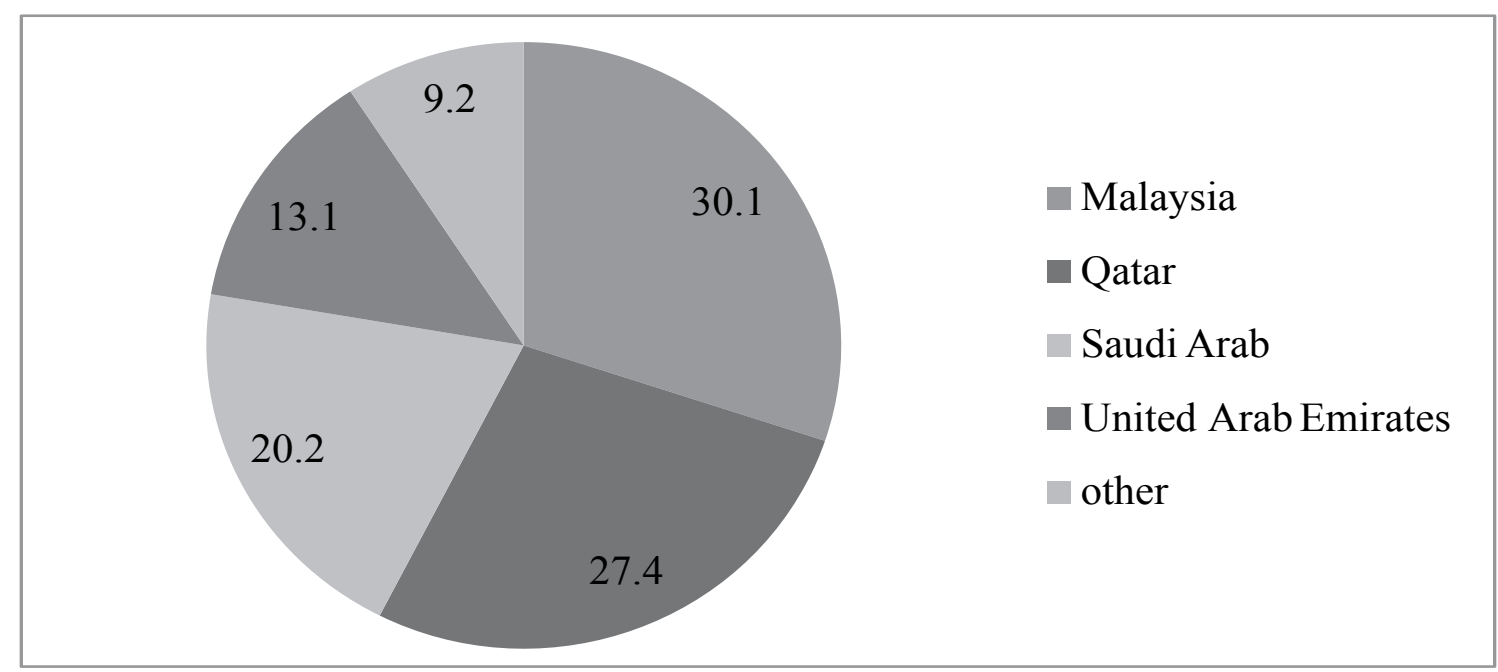

Source: Ministry of Labor, Employment and Social Security, 2018/19

Figure 2 reveals that Malaysia is the first attractive destination for Nepali labor migrants. Till mid-March of FY 2018/19, out of total number of workers migrated for foreign employment, 30.1 percent workers have been migrated to Malaysia, 27.4 percent to Qatar, 20.2 percent to Saudi Arabia, 13.1 percent to United Arab Emirates and 9.2 percent to other countries. 


\section{Remittances}

International migration has become one of the main sources for earning foreign currency and it has played pivotal role in minimizing the unemployment problem in Nepal. Earning of migrant labors called 'remittance' entered into Nepal long ago when Nepalese youths joined British Army known as 'Gurkhas'. But the Labor Act 1985 came as a boon for facilitating foreign employment and opening up avenues for the private sector (Shrestha, 2008).

As with the migration rate, the volume of remittances and their contribution to household economy has increased significantly in recent times. It can play significant role in making overall development of the nation if inward remittance is used to enhance domestic investment level and domestic consumption level of the nation. In terms of remittance inflows as percent of GDP, Nepal is the largest remittance receiver among all countries.

Figure 3: Distribution of remittance inflow as percent of GDP in the world, 2019.

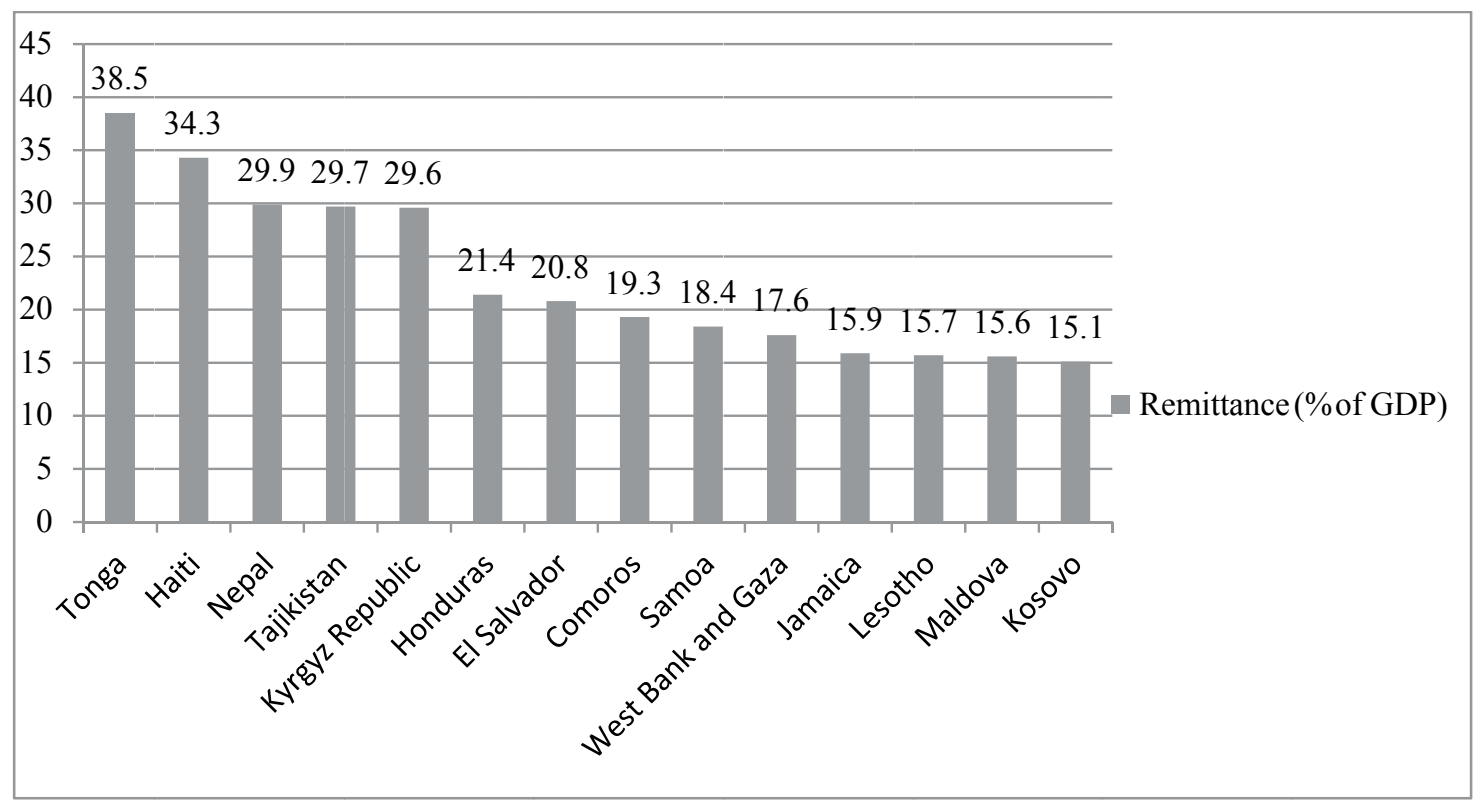

Source: World Bank, 2019

The figure 3 shows the highest remittances as a share of gross domestic product (GDP) in 2019 are Tonga 38.5 percent, Haiti 34.3 percent, Nepal 29.9 percent, Tajikistan 29.7 percent, and the Kyrgyz Republic 29.6 percent. This share in Nepal's GDP stands as the third largest in the world than Tonga and Haiti. 
Figure 4: Share of remittances inflow to Nepal, 2000/01-2018/19

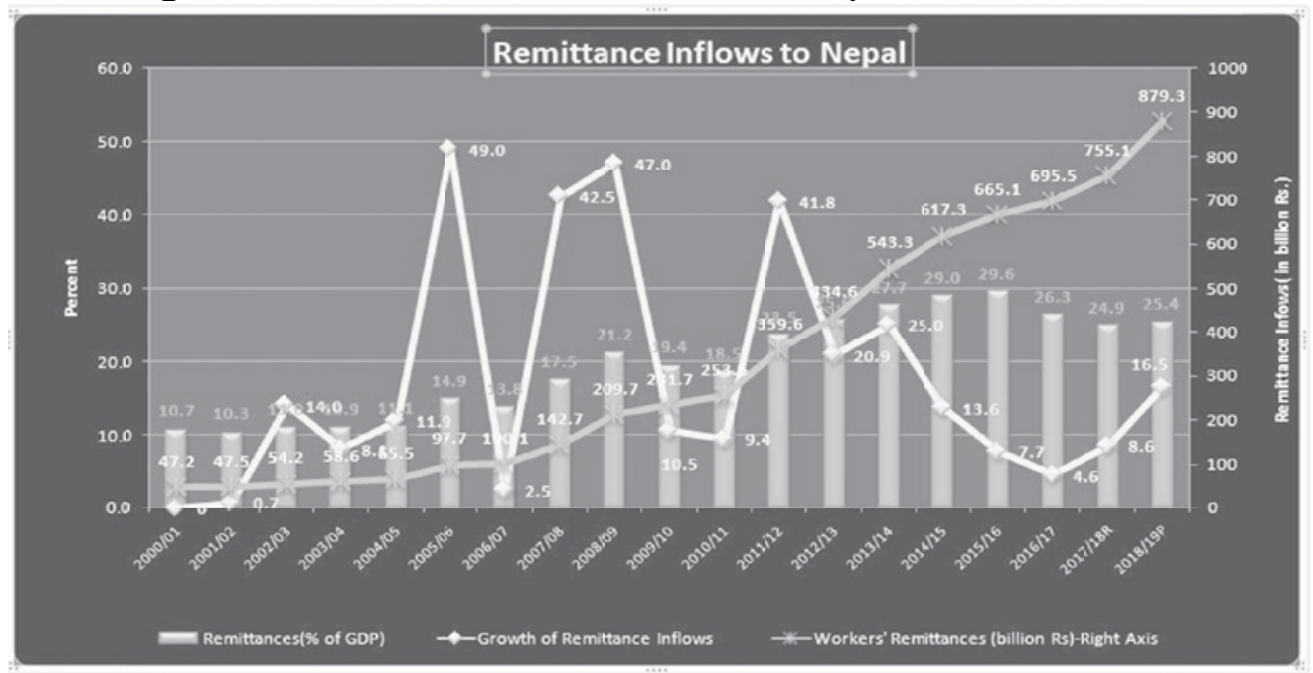

Source: https:// siddhabhatta.blogspot.com/2019

Figure 4 shows that the remittance inflows has increased almost 18 -fold during the last 19 years from Rs. 47 billion in 2001 to Rs. 879 billion in 2019. As percent of GDP, remittance inflow increased from 10.7 percent in 2001 to 29.6 percent in 2016 and then decreased gradually to 25.4 percent in 2019.Migrant remittances are a significant and vital financial source for labor exporting countries, therefore the issue of their effects is of utmost importance.

\section{Conclusion}

International labor migration and remittances are decisive determinant of Nepal's economic and social development and essential elements of its policy strategies. Nepal has a long history of emigration and it is in increasing trends. Now, however, migration to Gulf States and Malaysia has increased greatly, the participation of women in this emigration for work in foreign countries has been increasing too. Nepal has observed the largely growing phenomena of an absent population over the census periods. Whereas the 2001 census recorded that there was an absent population of 762,181 , the 2011 census identified more than double that is 1,921,494 absent people, 7.3 percent of the total population. Unexpectedly, the foreign labor migration has developed in such a way, which has shifted the agricultural based economy towards remittance based economy in Nepal. As with the migration rate, the volume of remittances and their contribution to household economy has increased significantly in recent times. The share in Nepal's GDP stands as the third largest in the world. While on one hand, the country on the supply 
side is highly dependent on the export of the services of its work force, it has, on the other hand insignificant influence on the global labor market. While international labor migration and remittance inflow is seen to be increasing, the government should take this opportunity to make and implement investment friendly policy to motivate individuals to invest in productive sector and utilize returnee's potential to their best.

\section{References}

Bhatta, S. R. (2019). Blog on Economic Issues. https:// siddhabhatta.blogspot.com/ on January 28, 2020.

Bhattarai, P. (2005). Migration of Nepalese youth for foreign employment: Problem and prospects. Kathmandu. A review of existing government policies and programmes. Nepal.

Central Bureau of Statistics. (2014). Population monograph of Nepal. Vol. I, Kathmandu: National Planning Commission Secretariat, Ramshahpath, Nepal.

Gurung, G. (2004). An overview of overseas employment in Nepal. Kathmandu: International labor office. https://www.ilo.org/kathmandu/whatwedo/publications/WCMS_116815/lang--en/ index.htm.

International Organization for Migration (IOM). (2008).World migration 2008: Managing labor mobility in the evolving global economy, World migration report series. Geneva: International Organization for Migration, Switzerland, Vol.4.

Kollmair, M., Manandhar, S., Subedi, B. \& Thieme, S. (2006). New figures for old stories: Migration and Remittances in Nepal. Migration Letters, 3(2): 15 1-160.

Ministry of Finance (MoF). (2019). Economic survey 2018/19. Kathmandu: Government of Nepal, Nepal.

Ministry of Labor Employment (MoLF). (2016). Labor migration for employment: A Status report for Nepal: 2014/15 Kathmandu: Government of Nepal, Nepal.

Ministry of Labor Employment (MoLE). (2018). Labor Migration for Employment: A status report for Nepal: 2015/16-2016/17. Kathmandu: Government of Nepal, Nepal.

Nepal Institute of Development Studies (NIDS). (2011). Nepal migration yearbook 2010. Kathmandu: Nepal.

Seddon, D. (2005).Nepal's dependence on exporting labor. Washington DC. https://www. migrationinformation.org/USfocus/display.cfm?ID=277.

Shrestha, B. (2008). Contribution of foreign employment and remittances to Nepalese economy. Economic Review, 20, 1-15.

United Nation (UN). (2017). International Migration Report 2017: Highlights. New York: United Nations.

World Bank (WB). (2009). Migration and Remittances fact book. Washington: World Bank, United States.

World Bank (WB). (2019). Migration and remittances, recent development and outlook. Migration and development brief 28. https://www.worldbank.org/en/topic/labormarkets/brief/migrationand-remittances. 